\title{
PRODUCTIVE PERFORMANCE, CARCASS TRAITS, LIPID PROFILE, ANTIOXIDANTS AND IMMUNITY OF GROWING RABBITS TREATED WITH GUM ARABIC UNDER EGYPTIAN SUMMER CONDITION
}

\author{
I.T. El-Ratel ${ }^{1 *}$, Rehab F. S. A. Ismail ${ }^{2}$ and Sara F. Fouda ${ }^{3}$ \\ ${ }^{1}$ Department of Poultry Production, Faculty of Agriculture, Damietta University, Damietta, Egypt \\ ${ }^{2}$ Department of Animal Production, Faculty of Agriculture, Mansoura University, Mansoura, Egypt \\ ${ }^{3}$ Department of Poultry Production, Faculty of Agriculture, Mansoura University, Mansoura, Egypt \\ * Author for correspondence: El-Ratel, I.T, E-mail: ibrahim.talat81@ yahoo.com
}

(Received 26/9/2018, accepted 15/11/2018)

\section{SUMMARY}

$\mathrm{E}$ ffect of Gum Arabic (GA), as natural antioxidant in the diet, on growth, carcass, digestibility, liver and kidney functions, antioxidant capacity, immunity, thyroid and testosterone hormones of growing rabbits was studied under Egyptian hot condition. Male APRI line rabbits (n=90) were assigned into 3 groups fed basal diet with 0 (T1), 1 (T2) and 2 (T3) kg GA/ton. Growth performance parameters and viability rate were recorded at age intervals from 5 to 11 wk. Digestibility coefficients, carcass traits, serum biochemicals, antioxidant, immunity, and thyroid and testosterone hormones were determined at $11 \mathrm{wk}$ of age. Results revealed that GA addition increased $(\mathrm{P}<0.05)$ growth performance, carcass traits (hind parts and dressing), serum total proteins, albumin, globulin, high-density lipoproteins, glucose, total antioxidant capacity, immunoglobulins, triiodothyronine, tetraiodothyronine and testosterone concentrations. Relative weight of carcass foreparts, weight of full digestive tract, cholesterol, triglycerides and low-density lipoproteins, hepato and renal somatic indexes, urea and malondialdehyde decreased $(\mathrm{P}<0.05)$ as affected by GA. In conclusion, dietary supplementation with both levels of GA can enhance productive performance, lipid profile, immune response and antioxidant defense system of growing rabbits under Egyptian summer conditions. The best results were obtained with adding $2 \mathrm{~kg} \mathrm{GA} / \mathrm{ton}$ diet.

Keywords: Rabbits, Arabic gum, growth performance, antioxidant status and immunity.

\section{INTRODUCTION}

The major threats for progress of rabbit industry are global warming and climate change (El Saidy et al., 2016). The thermo-neutral zone (comfortable zone) of rabbits was reported to be from 18 to $21^{\circ} \mathrm{C}$ (AlZafry and Medan, 2012). Under hot condition in Egypt, the heat stress (HS) is associated with high relative humidity ( $\geq 85 \%$ ) during the day time and may be $100 \%$ at the night time (Marai et al., 2007). In rabbits, HS induces alterations in energy, water and mineral balances as well as blood characteristics and hormonal levels (Al-Zafry and Medan, 2012), which adversely affect their growth performance, reproductive efficiency and immune response (Finzi et al., 2010; Aggarwal and Upadhyay, 2013). Also, lipid oxidant, as a consequence of increasing generation of free radical and increasing reactive oxygen species (ROS), induce oxidative stress in heat stressed rabbits (Hassan et al., 2016). Additionally, chronic HS may reduce metabolic oxidation capacity due to a self-propagating scavenging system (Azad et al., 2010).

Many in vivo studies confirmed that dietary natural antioxidant supplementation is important in ameliorating impacts of HS (McKee and Harrison, 2013). To generate a suitable environment for free radicals withdrawal by antioxidants, a balance in the animal physiological activities is required (Imik et al., 2010). In this respect, Gum Arabic (GA), green tea, curcumin, as natural plant antioxidants, have paid great interest from livestock producers (Basavaraj et al., 2011; El-Ratel et al., 2017). These antioxidants can be used with ease at a low price to the daily diet without adverse effects (Tawfeek et al., 2014). 
The GA is an edible, dried sticky exudate obtained from stems and branches of Acacia seyal and Acacia Senegal and rich in non-viscous soluble fibers (Abdelkareem et al., 2016). It is a complex polysaccharides of high molecular weight, containing neutral and acids sugars such as rhamnose, arabinose, galactose and glucuronic acid (Wyasu and Okereke, 2012), and minerals like $\mathrm{Ca}, \mathrm{Mg}, \mathrm{K}, \mathrm{Na}$ and P (Patel and Goyal, 2015). The GA is widely used in the industry of pharmacology and foods, as an emulsifier and stabilizer (Ayaz et al., 2017). In Arabic folk, GA is used medically in patients who suffer with chronic renal failure (Al-Majed et al., 2002). Also, GA is characterized by various biological effects, including nephro-protecting activity and different properties as antioxidant, antibacterial, antiviral, and anti-inflammatory (Jaafar et al., 2016).

The antioxidant properties of GA are documented in a variety of animal model system by Rehman et al. (2004). The GA as antioxidant contains phyto-constituents, including flavone, catechin, polyphenols, tannins, chalcones, alkaloids and flavonoids (Pal et al., 2014). These compounds have the ability to remove the free radicals, antioxidant enzymes activation and oxidases inhibition (Ali et al., 2009). Also, GA increases nitrogen excretion in feces and lowers urea-nitrogen concentration in blood serum of patients severing from chronic renal failure (Bliss et al., 1996). Furthermore, enhancement in the productive performance of growing rabbits fed diet with GA supplementation was reported by Amber et al. (2017). So far, little evidence is yet available regarding the evaluation the potential beneficial role of GA in growth parameters and physiological status of heat stressed rabbits.

Therefore, the current study aimed to investigate the effect of dietary supplementing different levels of Gum Arabic (0,1 and $2 \mathrm{~kg} /$ ton diet) as antioxidants on growth performance, carcass traits, digestibility coefficients, liver and kidney functions, antioxidant capacity, immune response, thyroid and testosterone hormones in growing rabbits reared under hot climatic condition in Egypt.

\section{MATERIALS AND METHODS}

The current experiment was conducted at Experimental Rabbitary Farm, and Physiology and Biotechnology Laboratory, Animal Production Department, Faculty of Agriculture, Mansoura University, Egypt, during the period from July to September 2017.

Total of 90 male APRI line rabbits (Egyptian line selected for litter weight at weaning according to Abou Khadiga et al. (2010) weaned at 5 weeks of age was used in this study. Throughout an experimental period from 5 to 11 weeks of age, rabbits were housed individually in galvanized wire cages $(35 \times 35 \times$ $60 \mathrm{~cm}$ ). Rabbits were kept under the same managerial conditions. Rabbits were fed ad. libitum and sufficient feeds were daily offered at 7 a.m., while water was available through cage nipple.

All experimental rabbits were assigned randomly into 3 similar groups, 30 animals in each group. Rabbits in the $1^{\text {st }}$ treatment (T1) were fed a commercial pelleted diet without any supplementation (control diet), while animals in the second (T2) and third (T3) treatment were fed the control diet supplemented with 1 and $2 \mathrm{~kg} \mathrm{GA} /$ ton diet, respectively. The control diet was formulated to cover the recommended nutrient requirements of growing rabbits according to NRC (1977) as shown in Table (1). Chemical composition of the control diet and GA based on dry matter (DM) was carried out according to the standard methods of AOAC (2012) and presented in Table (2).

Table (1): Ingredients of the control diet used for feeding rabbits in the experimental treatments.

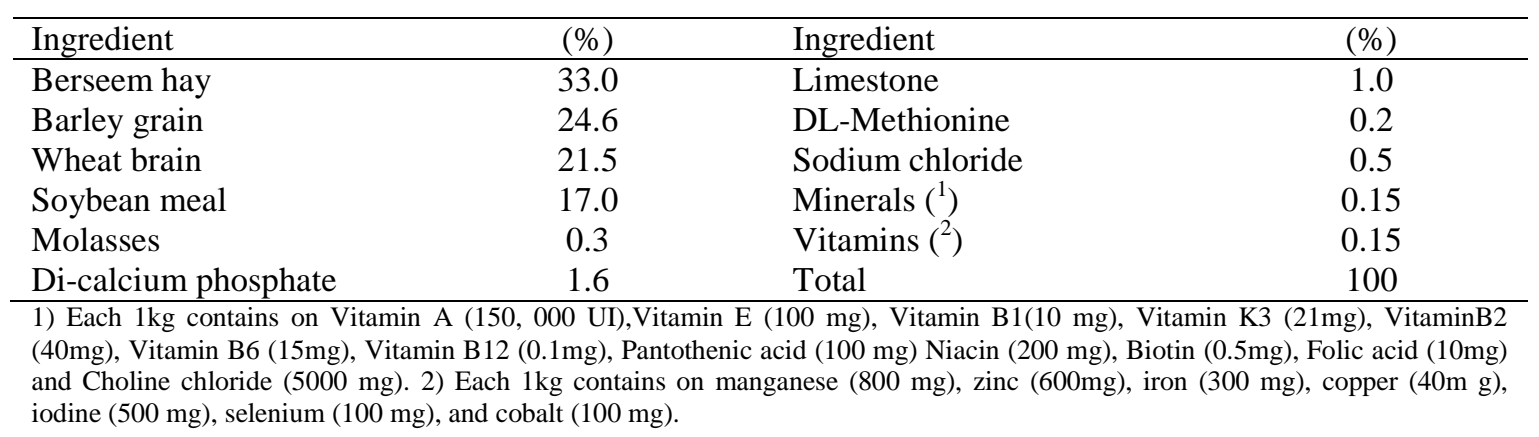


Egyptian J. Nutrition and Feeds (2019)

Table (2): Chemical analysis of the control diet and Gum Arabic.

\begin{tabular}{lcc}
\hline Item & Control diet & Gum Arabic \\
\hline Dry matter (\%) & 85.8 & 87.0 \\
Chemical analysis (on DM basis, \%): & & \\
Crude protein & 17.36 & 3.71 \\
Crude fiber & 13.45 & 7.98 \\
Ether extract & 1.61 & 0.43 \\
Nitrogen free extract & 61.77 & 85.15 \\
Ash & 5.81 & 2.73 \\
Digestible energy (kcal/ kg) & 2412 & 1387 \\
\hline
\end{tabular}

During the experimental period, live body weight and feed intake were weekly recorded, then average daily weight gain, feed intake and feed conversion ratio were calculated at age intervals of 5-8, 8-11 and 5-11 wk. Also, dead rabbits were recorded, then viability rate was computed during the entire length of the experimental period (5-11 wk). All rabbits were weighed in the morning before offering additional feeds, while daily feed intake was recorded by subtracting weight of the residual amounts of feed from the offered feed before putting the new ones at 7 a.m.

At the last week of the experimental period, 5 rabbits from each group were randomly chosen and individually housed in metabolic cages for 7 days digestibility trial, 4 days adaptation period and 3 days for feed intake determination and collection of feces in the morning (7 a.m.) and evening (7 p.m.). The daily collected feces from each rabbit were freshly weighed, then the feces of three collection days was pooled for each rabbit, then $50 \%$ subsample was taken for each rabbit. Feces were oven dried at $60{ }^{\circ} \mathrm{C}$ for $24 \mathrm{~h}$, and stored for chemical analysis according AOAC (2012).

After the termination of growing period (5-11 wk of age), other five rabbits (not used in digestibility trails) from each group were randomly chosen, fasted for $12 \mathrm{~h}$, individually weighed and immediately slaughtered to estimate some carcass traits. Net carcasses weight was recorded after bleeding and rabbits, being skinned and eviscerated. Weights of inedible organs (pelt distal leg and full digestive tract) was calculated relative to pre-slaughtered weight, while weights of carcass parts (fore, loin and hind) and edible organs (head, lunges, heart, liver and kidneys) were calculated relative to carcass plus edible organs weight. Dressing rate was calculated by dividing the carcass plus edible organs weight on preslaughter weight. Hepato and renal somatic indices were recorded as absolute weight of each organ relative to pre-slaughtered weight. Immediately after slaughtering, meat samples were taken from hind carcass parts of each of five rabbits in each group, then dried at $60^{\mathrm{oC}}$ for $48 \mathrm{~h}$ and grounded for approximate chemical analysis.

At the termination of the experimental period (11 wk of age), blood samples were collected from three animals in each group during slaughtering into sterile tubes. Blood samples were centrifuged immediately at $3500 \mathrm{rpm}$ for $15 \mathrm{~min}$, then blood serum was isolated and kept at $-20^{\circ} \mathrm{C}$ until assayed. Concentrations of serum total proteins, TP and albumin, AL (Valzitidis, 1977), glucose (Kaplan, 1984), total cholesterol, TC (Thomas, 1992), triglycerides, Tri (Fossati, 1982), high density lipoproteins, HDL (Assmann, 1979), low density lipoproteins, LDL (Bauer, 1982), urea (Tabacco et al., 1979) and creatinine (Henry, 1984) were determined. However, globulin (GL) concentration was determined by difference. Activity of aspartate (AST) and alanine (ALT) transaminases were also determined in serum according to Reitman and Frankel (1957). Hormonal concentration of thyroid gland (triiodothyronine, $\mathrm{T}_{3}$ and tetraiodothyronine, $\mathrm{T}_{4}$ ), and testosterone was assayed by radio-inmmuno-assay (RIA). Oxidative status, including total antioxidant capacity (TAC) and malondialdehyde (MDA) was assayed. Immunoglobulins (IgG, IgA and IgM) were determined by ELISA technique.

Data were statistically analyzed by one-way ANOVA design (SPSS 16.0) for Windows (Chicago, IL, USA) to study the effect of treatment on growth performance parameters at each age or age interval throughout the experimental period. However, other data were analyzed only at the end of the experimental period. Completely randomized design was used based on the following model: Yij $=\mu+$ $\mathrm{Ti}+$ eij, where $\mu=$ the overall mean, $\mathrm{Ti}=$ treatment (1-3), and eij $=$ residual error. Viability rate and carcass traits percentages were statistically analyzed using Chi-Square test. Differences among treatment means were set by Duncan's multiple range test (Duncan, 1955) at $\mathrm{P}<0.05$. 


\section{RESULTS AND DISCUSSION}

\section{Growth performance:}

Growth performance parameters, including live body weight and daily weight gain of rabbits were higher in treated groups (T2 and T3) than in control one (T1), but the significant $(\mathrm{P}<0.05)$ differences were obtained only for live body weight at 8 and $11 \mathrm{wk}$ of age and for daily weight gain at 5-8 and 5-11 wk of age intervals. The differences in live body weight and daily weight gain between $\mathrm{T} 2$ and $\mathrm{T} 3$ were not significant. However, the effect of GA on daily feed intake and feed conversion ratio were not significant at all age intervals, but viability rate during the entire length of the experimental period was higher in T3 than in T1 and T2 (Table 3). These results indicated beneficial effects of dietary supplementation of GA at both levels on growth performance of growing rabbits.

Table (3): Effect of dietary Arabic gum supplementation on growth performance parameters of APRI growing rabbits at different ages.

\begin{tabular}{|c|c|c|c|c|}
\hline \multirow{2}{*}{ Item } & \multirow{2}{*}{ Control (T1) } & \multicolumn{2}{|c|}{ Experimental group } & \multirow{2}{*}{ P-Value } \\
\hline & & T2 (1kg GA/ton diet) & T3 (2 kg GA/ton diet) & \\
\hline \multicolumn{5}{|c|}{ Average live body weight (g) } \\
\hline At 5 wk (Initial) & $726.6 \pm 7.77$ & $729.5 \pm 7.75$ & $727.2 \pm 8.65$ & 0.966 \\
\hline At $8 \mathrm{wk}$ & $1324.4 \pm 17.6^{\mathrm{b}}$ & $1378.1 \pm 18.01^{\mathrm{a}}$ & $1388.9 \pm 16.76^{\mathrm{a}}$ & 0.024 \\
\hline At 11 wk (Final) & $1994.3 \pm 26.6^{\mathrm{b}}$ & $2076.0 \pm 34.07^{\mathrm{a}}$ & $2097.4 \pm 24.54^{\mathrm{a}}$ & 0.034 \\
\hline \multicolumn{5}{|c|}{ Average daily gain $(\mathrm{g})$} \\
\hline At $5 \sim 8 \mathrm{wk}$ & $28.46 \pm 0.72^{\mathrm{b}}$ & $30.89 \pm 0.75^{\mathrm{a}}$ & $31.51 \pm 0.70^{\mathrm{a}}$ & 0.010 \\
\hline At $8 \sim 11 \mathrm{wk}$ & $31.96 \pm 0.73$ & $33.23 \pm 0.94$ & $33.74 \pm 0.61$ & 0.254 \\
\hline At $5 \sim 11 \mathrm{wk}$ & $30.13 \pm 0.57^{b}$ & $32.06 \pm 0.77^{\mathrm{a}}$ & $32.63 \pm 0.56^{\mathrm{a}}$ & 0.020 \\
\hline \multicolumn{5}{|c|}{ Average daily feed intake $(\mathrm{g})$} \\
\hline At $5 \sim 8 \mathrm{wk}$ & $101.6 \pm 3.26$ & $109.6 \pm 2.66$ & $110.6 \pm 2.68$ & 0.059 \\
\hline At $8 \sim 11 \mathrm{wk}$ & $159.8 \pm 2.47$ & $165.8 \pm 3.08$ & $166.2 \pm 3.02$ & 0.222 \\
\hline At $5 \sim 11 \mathrm{wk}$ & $130.7 \pm 2.59$ & $137.8 \pm 2.69$ & $138.4 \pm 2.72$ & 0.088 \\
\hline \multicolumn{5}{|c|}{ Feed conversion ratio (g feed/g gain) } \\
\hline At $5 \sim 8$ wk & $3.57 \pm 0.07$ & $3.55 \pm 0.08$ & $3.51 \pm 0.08$ & 0.836 \\
\hline At $8 \sim 11 \mathrm{wk}$ & $5.00 \pm 0.08$ & $4.99 \pm 0.09$ & $4.93 \pm 0.03$ & 0.503 \\
\hline At $5 \sim 11 \mathrm{wk}$ & $4.34 \pm 0.05$ & $4.27 \pm 0.07$ & $4.24 \pm 0.05$ & 0.436 \\
\hline Viability rate $(\%)$ & 93.33 & 93.33 & 96.66 & - \\
\hline
\end{tabular}

Heat stress alleviate lipid oxidant and consequently increases free radical generation which rises ROS production inducing cellular oxidative stress (Hassan et al., 2016). Therefore, impaired growth performance of heat stressed animals in control group (T1) as compared to those in treatment groups (T2 and T3), probably due to increasing ROS generation in T1, which may lead to oxidization and breakdown of biological molecules, inhabitation of some ATP-as activities, and many impairments in the intestinal tissues, growth and feed utilization (Payne and Southern, 2005; Josephine et al., 2008). Improving growth performance of rabbits in treatment groups was mainly explained by insignificant increase in their feed consumption against the negative effect of heat stress on feed intake of rabbits. The observed tendency of increase in feed intake in treatment groups may be attributed to that GA contains complex polysaccharide like rhamnose, arabinose, galactose and glucuronic acid (Wyasu and Okereke, 2012). These contents may improve palatability of diets supplemented with GA, and then feed consumption. In accordance with these findings, Amber et al. (2017) reported insignificant effect of dietary GA supplementation on increasing feed intake of growing rabbits. However, Nasir et al. (2008) reported unchanged feed intake of mice fed diet treated with GA.

The obtained results indicated significant improvement in weight and gain of rabbits in treatment groups without significant effect on feed intake and FCR. Several authors found that GA supplementation enhances the productive performance of growing rabbits (Tageldin et al., 2006; Liu et al., 2011; AlSagheer et al., 2017). The observed tendency of increasing rabbit viability rate, particularly, with the highest GA level (T3) may be attributed to that GA displays antimicrobial activity and ability to stimulate 
the intestinal absorption (Ali et al., 2009), which was in relation with improving antioxidant and immunity systems as affected by GA in our study. In general, natural antioxidants can decrease oxidative damage of intestinal mucosa and enhances rabbit productive performance (Kermauner and Laurenčič, 2008). In this respect, GA has powerful anti-oxidant action (Jaafar et al., 2016) as indicated in our study.

\section{Nutrient digestibility coefficients:}

Digestibility coefficients of all nutrients were higher in T2 and T3 than in T1, being the highest in T3, but the differences were not significant, indicating somewhat improvement of nutrient digestion in growing rabbits fed diet supplemented with GA (Table 4).

Table (4): Effect of dietary Gum Arabic supplementation on nutrient digestibility of APRI growing rabbits.

\begin{tabular}{lcccc}
\hline \multirow{2}{*}{ Nutrient $(\%)$} & \multirow{2}{*}{ Control (T1) } & \multicolumn{2}{c}{ Experimental group } & \multirow{2}{*}{$\mathrm{P}-$ Value } \\
\cline { 3 - 4 } & & $\mathrm{T} 2(1 \mathrm{~kg} \mathrm{GA} /$ ton diet $)$ & $\mathrm{T} 3(2 \mathrm{~kg}$ GA/ton diet $)$ & \\
\hline Organic matter & $69.26 \pm 1.02$ & $69.94 \pm 0.63$ & $71.12 \pm 0.67$ & 0.285 \\
Crude protein & $75.09 \pm 0.88$ & $75.60 \pm 0.57$ & $76.82 \pm 0.70$ & 0.265 \\
Crude fiber & $31.61 \pm 2.13$ & $35.26 \pm 2.20$ & $39.01 \pm 2.59$ & 0.119 \\
Ether extract & $82.08 \pm 2.26$ & $82.65 \pm 1.26$ & $84.87 \pm 1.27$ & 0.480 \\
Nitrogen free extract & $73.83 \pm 0.18$ & $74.25 \pm 0.21$ & $74.62 \pm 0.27$ & 0.085 \\
\hline
\end{tabular}

\section{Carcass traits:}

As presented in Table 5, relative weight of foreparts of carcass significantly $(\mathrm{P}<0.05)$ decreased, while hind parts significantly $(\mathrm{P}<0.05)$ increased in $\mathrm{T} 2$ and $\mathrm{T} 3$ compared with $\mathrm{T} 1$. However, relative weight of the middle parts (loin) and total edible organs was not affected significantly by GA treatment. Along with the positive effect of GA on increasing the hind parts of rabbit carcass, also weight of inedible organs relative to pre-slaughtered weight was significantly $(\mathrm{P}<0.05)$ higher in $\mathrm{T} 1$ than in $\mathrm{T} 3$, in term of relative weight of full digestive tract. These results reflected in significantly $(\mathrm{P}<0.05)$ the highest dressing percentage of rabbits in $\mathrm{T} 3$ and insignificant increase in dressing percentage of rabbits in $\mathrm{T} 2$ as compared to those in T1. Regard to the chemical composition of rabbit meat, GA had insignificant effect on contents of crude protein, ether extract and ash.

Table (5): Effect of dietary Gum Arabic supplementation on carcass traits of APRI growing rabbits.

\begin{tabular}{|c|c|c|c|c|}
\hline \multirow{2}{*}{ Item } & \multirow{2}{*}{ Control (T1) } & \multicolumn{2}{|c|}{ Experimental group } & \multirow[t]{2}{*}{ P -Value } \\
\hline & & T2 (1kg GA/ton diet) & T3 (2 kg GA/ton diet) & \\
\hline Slaughtered rabbits (n) & 5 & 5 & 5 & - \\
\hline \multicolumn{5}{|l|}{ Carcass part weight $(\%)$ : } \\
\hline Fore $*$ & $27.99 \pm 1.16^{\mathrm{a}}$ & $25.66 \pm 0.95^{\mathrm{b}}$ & $24.20 \pm 0.55^{\mathrm{b}}$ & 0.040 \\
\hline Loin* & $21.58 \pm 0.15$ & $21.64 \pm 0.08$ & $21.47 \pm 0.13$ & 0.641 \\
\hline Hind* & $32.78 \pm 0.67^{\mathrm{b}}$ & $35.15 \pm 1.03^{\mathrm{a}}$ & $36.81 \pm 1.26^{\mathrm{a}}$ & 0.048 \\
\hline Total edible organs $(\%) *$ & $17.65 \pm 0.11$ & $17.55 \pm 0.07$ & $17.52 \pm 0.15$ & 0.218 \\
\hline \multicolumn{5}{|l|}{ Inedible organs: } \\
\hline Blood $(\%) * *$ & $2.33 \pm 0.01$ & $2.34 \pm 0.01$ & $2.35 \pm 0.01$ & 0.390 \\
\hline Pelt distal leg $(\%) * *$ & $19.60 \pm 0.39$ & $18.37 \pm 0.57$ & $17.42 \pm 0.69$ & 0.055 \\
\hline Digestive tract $(\%) * *$ & $18.86 \pm 0.32^{\mathrm{a}}$ & $17.80 \pm 0.48^{\mathrm{ab}}$ & $17.02 \pm 0.59^{\mathrm{b}}$ & 0.042 \\
\hline Other losses $(\%) * *$ & $2.03 \pm 0.03$ & $2.13 \pm 0.03$ & $2.14 \pm 0.05$ & 0.065 \\
\hline Total $(\%) * *$ & $42.82 \pm 0.22^{\mathrm{a}}$ & $40.64 \pm 0.45^{\mathrm{b}}$ & $38.93 \pm 0.51^{\mathrm{b}}$ & 0.042 \\
\hline Dressing $(\%) * *$ & $57.18 \pm 0.71^{\mathrm{b}}$ & $59.36 \pm 1.02^{\mathrm{ab}}$ & $61.07 \pm 1.25^{\mathrm{a}}$ & 0.050 \\
\hline \multicolumn{5}{|l|}{ Chemical composition (\%): } \\
\hline Crude protein & $18.64 \pm 0.02$ & $18.73 \pm 0.05$ & $18.68 \pm 0.04$ & 0.411 \\
\hline Ether extract & $3.48 \pm 0.03$ & $3.54 \pm 0.02$ & $3.45 \pm 0.03$ & 0.168 \\
\hline Ash & $1.98 \pm 0.01$ & $2.02 \pm 0.02$ & $1.97 \pm 0.01$ & 0.114 \\
\hline
\end{tabular}


The obtained results are in agreement with several investigators. In this way, Amber et al. (2017) found reduction in the digestive tract weight relative to fasting weight of rabbits fed diet supplemented with GA at a level of 1.5\%. Also, Dalle Zotte et al. (2012) reported that GA level did not provide improvements in carcass traits of growing rabbits. It was observed that increasing LBW of rabbits fed GA supplemented diets in the present study was focused on increasing the relative weight of hind parts of the carcass, reflecting higher dressing percentage of rabbits in T2 and T3 without effects on chemical analysis of rabbit meat. Although feed intake was insignificantly higher in T2 and T3 than in T1, full digestive tract relative to pre-slaughter weight was significantly $(\mathrm{P}<0.05)$ lower in $\mathrm{T} 2$ and $\mathrm{T} 3$ than in $\mathrm{T} 1$, which may indicate a positive effect of GA on rate of passage within the digestive tract of rabbits. These results indicated that GA had no adverse effects on the carcass traits and meat quality of rabbits.

\section{Liver and kidney functions:}

Data of somatic indices indicated significantly the highest hepato- and renal somatic indices in T3 compared with $\mathrm{T} 1$ and $\mathrm{T} 2$. Concentration of protein fractions, indicated significantly better protein metabolism of rabbits in T2 and T3 than T1.The observed insignificant differences in serum aspartate and alanine transaminases activity and in serum urea concentration as well as significant $(\mathrm{P}<0.05)$ decrease in serum creatinine concentration in T2 and T3 than in T1 reflected normal liver and kidney function of rabbits in treatment groups (Table 6). The present results indicate no adverse effects of dietary GA supplementation were detected on protein metabolism, feed utilization and enzyme activity leading to functional liver and kidney during the growing period.

Similarly, Amber et al. (2017) found significant increase in serum TP, AL and GL concentrations and insignificant differences in AST and ALT activities in rabbits fed GA supplemented diet as compared to their controls. These results may indicate normal metabolism and liver function of rabbits in treatment groups (Khojah, 2017). Moreover, the recorded insignificant differences in urea and decreasing creatinine concentration in serum of rabbits in treatment groups as compared to control may indicate potential and positive effect of dietary GA supplementation on feed utilization and normal kidney function.

Table (6): Effect of dietary Gum Arabic supplementation on liver and kidney functions of APRI growing rabbits.

\begin{tabular}{|c|c|c|c|c|}
\hline \multirow{2}{*}{ Item } & \multirow{2}{*}{ Control (T1) } & \multicolumn{2}{|c|}{ Experimental group } & \multirow{2}{*}{ P -Value } \\
\hline & & T2 (1kg GA/ton diet) & T3 (2 kg GA/ton diet) & \\
\hline Hepato-somatic index & $3.08 \pm 0.015^{\mathrm{a}}$ & $3.02 \pm 0.02^{\mathrm{ab}}$ & $2.99 \pm 0.03^{b}$ & 0.042 \\
\hline \multicolumn{5}{|l|}{ Protein fractions $(\mathrm{g} / \mathrm{dl})$ : } \\
\hline Total protein & $5.95 \pm 0.08^{\mathrm{b}}$ & $6.26 \pm 0.03^{\mathrm{a}}$ & $6.33 \pm 0.02^{\mathrm{a}}$ & 0.003 \\
\hline Albumin & $3.76 \pm 0.03^{\mathrm{b}}$ & $3.96 \pm 0.03^{\mathrm{a}}$ & $4.03 \pm 0.03^{\mathrm{a}}$ & 0.002 \\
\hline globulin & $2.19 \pm 0.02^{\mathrm{b}}$ & $2.30 \pm 0.04^{\mathrm{a}}$ & $2.30 \pm 0.02^{\mathrm{a}}$ & 0.007 \\
\hline \multicolumn{5}{|c|}{ Transaminases activity (IU/l): } \\
\hline Aspartate & $38.67 \pm 1.45$ & $38.33 \pm 1.67$ & $37.67 \pm 1.85$ & 0.912 \\
\hline Alanine & $34.43 \pm 0.86$ & $34.00 \pm 0.58$ & $33.33 \pm 0.34$ & 0.505 \\
\hline Renal-somatic index & $0.96 \pm 0.02^{\mathrm{a}}$ & $0.89 \pm 0.03^{\mathrm{ab}}$ & $0.83 \pm 0.04^{\mathrm{b}}$ & 0.050 \\
\hline \multicolumn{5}{|c|}{ Protein metabolites (mg/dl): } \\
\hline Urea & $46.33 \pm 0.89$ & $44.67 \pm 0.88$ & $42.33 \pm 1.45$ & 0.108 \\
\hline Creatinine & $1.067 \pm 0.06^{\mathrm{a}}$ & $0.853 \pm 0.02^{\mathrm{b}}$ & $0.823 \pm 0.01^{\mathrm{b}}$ & 0.007 \\
\hline
\end{tabular}

\section{Lipid profile and glucose level:}

Dietary GA supplementation in both treatment groups ( $\mathrm{T} 2$ and $\mathrm{T} 3)$ significantly $(\mathrm{P}<0.05)$ reduced serum total cholesterol, triglycerides and low-density lipoproteins concentrations, and increased highdensity lipoproteins and glucose concentrations compared with control group (T1) as illustrated in Table 7. These results indicated remarkable effect on lipid profile of growing rabbits. Similar trends were reported in serum of rabbits (Amber et al., 2017) and rats (Eyibo et al., 2018). Also, a decrease in blood lipids profile was observed in health and diabetes patients treated with dietary fibers as GA (Lattimer and Haub, 2010). The trend of change in lipid profile of growing rabbits fed GA supplemented diet could be attributed to marked reduction in absorption and/or synthesis of cholesterol in the gastro-intestinal tract (Slavin, 2005). Furthermore, Kishimoto et al. (2006) stated that specific bacteria species is most likely 
responsible for GA fermentation to propionate, which could limit key enzymes induction of cholesterol metabolism, subsequently decreasing cholesterol level in blood (Illman and Topping, 1988).

Regarding the effect of GA on serum glucose level, Mohamed et al. (2015) reported an increase in glucose level in rats treated with GA. Also, plasma glucose was significantly higher for rabbits fed 5\% GA diet (Tageldin et al., 2006). This increase in glucose level may be attributed to that GA supplementation significantly reduced urinary glucose excretion, $\mathrm{Na}+$ excretion and urinary volume (Nasir et al., 2012).

Table (7): Effect of dietary Gum Arabic supplementation on serum lipid profile and glucose level in of APRI growing rabbits.

\begin{tabular}{|c|c|c|c|c|}
\hline \multirow{2}{*}{ Item } & \multirow{2}{*}{ Control (T1) } & \multicolumn{2}{|c|}{ Experimental group } & \multirow{2}{*}{$\begin{array}{c}\mathrm{P}- \\
\text { Value }\end{array}$} \\
\hline & & T2 (1kg GA/ton diet) & T3 (2 kg GA/ton diet) & \\
\hline \multicolumn{5}{|l|}{ Lipid profile (mg/dl): } \\
\hline Total cholesterol & $137.33 \pm 1.45^{\mathrm{a}}$ & $130.00 \pm 1.16^{\mathrm{b}}$ & $126.33 \pm 0.88^{b}$ & 0.002 \\
\hline Triglycerides & $94.00 \pm 2.08^{\mathrm{a}}$ & $86.33 \pm 0.88^{\mathrm{b}}$ & $82.33 \pm 1.45^{\mathrm{b}}$ & 0.005 \\
\hline High-density lipoproteins & $59.40 \pm 0.31^{\mathrm{b}}$ & $64.33 \pm 1.20^{\mathrm{a}}$ & $67.00 \pm 1.54^{\mathrm{a}}$ & 0.009 \\
\hline Low-density lipoproteins & $42.33 \pm 1.45^{\mathrm{a}}$ & $35.00 \pm 1.73^{\mathrm{b}}$ & $31.67 \pm 1.20^{\mathrm{b}}$ & 0.006 \\
\hline \multicolumn{5}{|c|}{ Carbohydrate metabolisms (mg/dl): } \\
\hline Glucose & $105.67 \pm 3.48^{\mathrm{b}}$ & $117.67 \pm 1.45^{\mathrm{a}}$ & $122.00 \pm 1.73^{\mathrm{a}}$ & 0.007 \\
\hline
\end{tabular}

\section{Oxidative status and immunity response:}

Concentration of total antioxidant capacity significantly increased $(\mathrm{P}<0.05)$ only in $\mathrm{T} 3$ compared with other treatments (T1 and $\mathrm{T} 2)$, while malondialdehyde concentration significantly $(\mathrm{P}<0.05)$ decreased in T2 and T3 compared with T1 (Table 6), reflecting better antioxidant defense system of rabbits in treatment groups (T2 and T3) than in T1 (control group). Also, immunoglobulin (IgG) concentration was significantly $(\mathrm{P}<0.05)$ the highest in $\mathrm{T} 3$, moderate in $\mathrm{T} 2$ and the lowest in $\mathrm{T} 1$, while both treatment groups ( 2 and $\mathrm{T} 3)$ showed significantly $(\mathrm{P}<0.05)$ higher immunoglobulins $(\operatorname{IgM}$ and $\operatorname{IgA})$ concentrations than in $\mathrm{T} 1$, reflecting higher immune response of $\mathrm{T} 2$ and $\mathrm{T} 3$ than in $\mathrm{T} 1$ (Table 8 ).

Table (8): Effect of dietary Gum Arabic supplementation on oxidative and immunity status of APRI growing rabbits.

\begin{tabular}{|c|c|c|c|c|}
\hline \multirow{2}{*}{ Item } & \multirow{2}{*}{ Control (T1) } & \multicolumn{2}{|c|}{ Experimental group } & \multirow{2}{*}{ P-Value } \\
\hline & & T2 (1kg GA/ton diet) & T3 (2 kg GA/ton diet) & \\
\hline \multicolumn{5}{|c|}{ Oxidative status (nmol/l): } \\
\hline TAC & $2.99 \pm 0.03^{b}$ & $3.02 \pm 0.02^{\mathrm{b}}$ & $3.08 \pm 0.015^{\mathrm{a}}$ & 0.042 \\
\hline Malondialdehyde & $7.95 \pm 0.08^{\mathrm{a}}$ & $6.26 \pm 0.03^{b}$ & $6.33 \pm 0.02^{\mathrm{b}}$ & 0.003 \\
\hline \multicolumn{5}{|c|}{ Immunity status (mg/dl): } \\
\hline $\operatorname{IgG}$ & $481.67 \pm 4.41^{\mathrm{c}}$ & $514.67 \pm 3.71^{\mathrm{b}}$ & $531.00 \pm 2.08^{\mathrm{a}}$ & 0.001 \\
\hline $\operatorname{IgM}$ & $150.33 \pm 0.88^{b}$ & $161.67 \pm 1.45^{\mathrm{a}}$ & $164.00 \pm 1.15^{\mathrm{a}}$ & 0.001 \\
\hline $\operatorname{IgA}$ & $136.00 \pm 2.08^{\mathrm{b}}$ & $147.67 \pm 1.45^{\mathrm{a}}$ & $152.00 \pm 1.73^{\mathrm{a}}$ & 0.002 \\
\hline
\end{tabular}

The beneficial effects of GA on rabbits of T2 and T3 may be attributable to the antioxidant properties of GA as reported by several authors, who indicated this fact in rats (Armogida et al., 2012; Gado and Aldahmash, 2013) as a result of presence of various antioxidant compounds like flavonoids and other polyphenolic compounds (Sadeek, 2018), and antioxidants molecules such as lysine, tyrosine and histidine amino acid residues (Park et al., 2005). In addition, rats administrated with GA significantly increased enzymatic antioxidants activity such as SOD, catalase, GSH and GPx (Sadeek, 2018) and increased TAC level in human (Kaddam et al., 2017). The GA may directly combine with free radicals, leading to their inactivation by decrease free radicals in the cells (Priscilla and Prince, 2009). According 
to the obtained results and those previously reported, GA is considered as a good anti-oxidant for improving antioxidant defense system (Kassem, 2015).

The present results proved the antioxidant properties of GA as found also on immunity of growing rabbits. Such results proved a negative relationship between TAC and MDA, while a positive relationship was observed between antioxidant and immunity systems. Also, GA supplementation resulted in significant improvement in immunoglobulins concentration (IgG, IgM and $\operatorname{IgA}$ ) in rabbits. Similar findings were obtained by kamal et al. (2018) in human and by Ali et al. (2013) in mice. Also, Ushida et al. (2011) and Ali et al. (2013) found an increase of anti-inflammatory cytokine IL10 and a decrease in tumor necrosis factor $\alpha$ expression in the adipose tissues of GA treated mice. The GA has a particularly strong effect on formation of IL-10 and IL-6, which regulate the immune response (Xuan et al., 2010). Moreover, GA seemed to block the function of hepatic macrophage (Gamal El-din et al., 2003). Such findings indicated that GA has advantageous on animal immunity as proved on rabbits in our study.

\section{Thyroid hormones $\left(\mathrm{T}_{3}\right.$ and $\left.\mathrm{T}_{4}\right)$ and testosterone level:}

Concentration of serum triiodothyronine was significantly $(\mathrm{P}<0.05)$ higher in $\mathrm{T} 3$ than in $\mathrm{T} 1$ and $\mathrm{T} 2$, while concentrations of serum tetraiodothyronine and testosterone significantly $(\mathrm{P}<0.05)$ increased in $\mathrm{T} 2$ and T3 than in T1 (Table 9).

Table (9): Effect of dietary Gum Arabic supplementation on serum concentration of thyroid and androgen hormones of APRI growing rabbits.

\begin{tabular}{|c|c|c|c|c|}
\hline \multirow{2}{*}{ Item } & \multirow{2}{*}{ Control (T1) } & \multicolumn{2}{|c|}{ Experimental group } & \multirow{2}{*}{ P -Value } \\
\hline & & T2 (1kg GA/ton diet) & T3 (2 kg GA/ton diet) & \\
\hline \multicolumn{5}{|c|}{ Thyroid hormones (ng/ml): } \\
\hline Triiodothyronine & $1.11 \pm 0.06^{\mathrm{b}}$ & $1.23 \pm 0.05^{\mathrm{a}}$ & $1.47 \pm 0.04^{\mathrm{a}}$ & 0.008 \\
\hline Tetraiodothyronine & $2.72 \pm 0.02^{\mathrm{c}}$ & $2.85 \pm 0.03^{b}$ & $3.95 \pm 0.05^{\mathrm{a}}$ & 0.001 \\
\hline \multicolumn{5}{|c|}{ Androgen hormone (ng/ml): } \\
\hline Testosterone & $2.350 \pm 0.03^{\mathrm{c}}$ & $2.817 \pm 0.06^{\mathrm{b}}$ & $3.00 \pm .01^{\mathrm{a}}$ & 0.001 \\
\hline
\end{tabular}

Beside different impacts of GA on performance of rabbits, our study indicated positively higher concentration of serum $\mathrm{T}_{3}$, which significantly decreases after submission to heat stress (Khalil et al., 2013). The observed increase in testosterone of rabbits treated with GA in our study was proved in rats by Jaafar et al. (2016), who concluded that GA administration reduced lipid peroxidation, improved the activities of testicular antioxidant enzymes and decreased damage of rat testes. Also, Fuhrman et al. (2000) showed that natural antioxidant may target cholesteryl ester hydrolase, which produce free cholesterol from cholesteryl esters for testosterone synthesis.

\section{CONCLUSION}

Conclusively, dietary supplementation with Gum Arabic (2 kg/ton diet) can enhance productive performance, lipid profile, immune response and antioxidant defense system of growing rabbits under Egyptian summer conditions without adversely effects on liver and kidney function. Gum Arabic can safely be used in diets as a natural antioxidant and metabolic agent in field of rabbit production.

\section{REFERENCES}

Abdelkareem, A.A., S.F. Jaafar, H.M. Hassan, H.M. Taha and Amal Z. Sifaldin (2016). Gum Arabic supplementation improved antioxidant status and alters expression of oxidative stress gene in ovary of mice fed high fat diet. Middle East Fertility Society Journal, 21: 101-108.

Abou Khadiga, G., Y.M.K. Youssef, K. Saleh, R.Y. Nofal and M. Baselga (2010). Genetic trend in selection for litter weight in two maternal lines of rabbits in Egypt. World Rabbit Sci., 18: 27-32. 
Aggarwal, A. and R. Upadhyay (2013). Heat stress and immune function. In: Aggarwal A, Upadhyay R (eds) Heat stress and animal productivity. Springer India, New Delhi, pp 113-136.

Ali, B.H., S. Beegam, I. Al-Lawati, M.I. Waly, M. Al Za'abi and A. Nemmar (2013). Comparative efficacy of three brands of gum acacia on adenine-induced chronic renal failure in rats. Physiol. Res., 62:47-56.

Ali, B.H., A. Ziada and G. Blunden (2009). Biological effects of Gum Arabic: a review of some recent research. Food Chem. Toxicol, 47: 1-8.

Al-Majed, A.A., A.M. Mostafa, A.C. Al-Rikabi and O.A. Al-Shabanah (2002). Protective effects of oral Arabic Gum administration on gentamicin- induced nephrotoxicity in rats. Pharmacol Res., 46: 445451.

Al-Sagheer, A.A., A.H. Daader, H.A. Gabr and Elham A. Abd El-Moniem (2017). Palliative effects of extra virgin olive oil, gallic acid, and lemongrass oil dietary supplementation on growth performance, digestibility, carcass traits, and antioxidant status of heat-stressed growing New Zealand White rabbits. Environ Sci Pollut Res., 24:6807-6818.

Al-Zafry, S. R. and M.S Medan (2012). Effects of vitamin E and selenium complex on heat-stressed rabbits. SCVMJ, XVII (2):129-138.

Amber, Kh, Fatma M. Abd El-Nabi, W.A. Morsy and Shama H.A. Morsy (2017). Gum Arabic as Prebiotic in Growing Rabbits Diet. Global Veterinaria, 19: 465-471.

AOAC (2012). Official Methods of Analysis, $19^{\text {th }}$ ed. Association of Official Analytical Chemists, Washington, DC, USA.

Armogida, M., R. Nistico and N.B. Mercuri (2012). Therapeutic potential of targeting hydrogen peroxide metabolism in the treatment of brain ischaemia. Br. J. Pharmacol., 166:1211-1224.

Assmann, G. (1979). Determination of high density lipoprotein cholesterol. Internist. 20: 559.

Ayaz, N.O., Kholoud S. Ramadan, Hoda E.A. Farid and Hanan S. Alnahdi (2017). Protective role and antioxidant activity of Arabic Gum against trichloroacetate-induced toxicity in liver of male rats. Indian J. Anim. Res., 51:303-309.

Azad, M.A.K., M. Kikusato, T. Maekawa, H .Shirakawa and M. Toyomizu (2010). Metabolic characteristics and oxidative damage to skeletal muscle in broiler chickens exposed to chronic heat stress. Comp. Biochem. Physiol., 155:401-406.

Basavaraj, M., V. Nagabhushana, N. Prakash, M.M. Appannavar, P.Wagmare and S. Mallikarjunapp (2011). Effect of Dietary Supplementation of Curcuma Longa on the Biochemical Profile and Meat Characteristics of Broiler Rabbits under Summer Stress. Veterinary World., 4:15-18.

Bauer, J.D. (1982). Clinical Laboratory Methods. $9^{\text {th }}$ Ed., the C.V. Company, Westline Ind ustrial Missouri 63116. Chapter 33: Pp. 555.

Bliss, D.Z., T.P. Stein, C.R. Schleifer and R.G. Setlle (1996). Effect of Gum Arabic on chronic renal failure .American Journal of Clinical Nutrition, 63:392 - 398.

Dalle Zotte, A., Z. Matics, P. Bohatir, A. Sartori, Z. Gerencsér, and Z. Szendrő (2012). Effect of dietary supplementation of chestnut hydrolysable tannin on digestive efficiency, growth performance and meat quality in growing rabbits. In: Proceedings of the $10^{\text {th }}$ World Rabbit Congress, Sharm El-Sheikh, Egypt, September 3-6, pp. 961-965.

Duncan, D.B (1955). Multiple range and Multiple F test. Biometrics, 11: 1-42.

El-Ratel, I.T., A.E. Abdel-Khalek, M.A. El-Harairy, Sara F. Fouda and Lamiaa Y. El-Bnawy (2017). Impact of green tea extract on reproductive performance, hematology, lipid metabolism and histogenesis of liver and kidney of rabbit does. Asian J. Anim. Vet. Adv., 12: 51-60.

El Saidy, N.R., F.E. Allam, T.M. Balabel and S.A. El-Midany (2016). Evaluation of using honey, cool water and levamisole against heat stress on different traits of rabbits under Egyptian summer conditions. World Vet J., 6:10-18. 
Eyibo, A.S., G. Istifanus, O.E. Blessing, A.D. Bogolnaan and Y. Denkok (2018). Determination of the Effect of Gum Arabic on Body Weight and Some Biochemical Parameters on Albino Wistar Rat. European Journal of Nutrition \& Food Safety, 8:14-19.

Finzi, A., P. Morera and G. Kuzminsky (2010). Sperm abnormalities as possible indicators of rabbit chronic heat stress. World Rabbit Sci., 4:157-161.

Fossati, P. (1982). Enzymatic colorimetric determination of triglycerides. Principle, L. Clin. Chem., 28:2077.

Fuhrman, B., N. Volkova, M. Rosenblat, and M. Aviram (2000). Lycopene synergistically inhibits LDL oxidation in combination with vitamin E, glabridin, rosmarinic acid, carnosic acid, or garlic. Antioxid Redox Signal, 2: 491-506.

Gado, A.M. and B.A. Aldahmash (2013). Antioxidant effect of Arabic Gum against mercuric chlorideinduced nephrotoxicity. Drug Des Devel Ther., 7:1245-1252.

Gamal El-Din, A. M., A. M. Mostafa, O. A. Al-Shabanah, A. M. Al-Bekairi, and M. N. Nagi (2003). Protective effect of Arabic Gum against acetaminophen-induced hepatotoxicity in mice," Pharmacological Research, 48:631-635.

Hassan, H.M.A., M.M. El-Moniary, Y. Hamouda, Eman F. El-Daly, Amani W. Youssef and Nafisa A. Abd El-Azeem (2016). Effect of Different Levels of Moringa oleifera Leaves Meal on Productive Performance, Carcass Characteristics and Some Blood Parameters of Broiler Chicks Reared under Heat Stress Conditions. Asian J. Anim. Vet. Adv., 11: 60-66.

Henry, R.J. (1974). Clinical Chemistry: Principles and Techniques. $2^{\text {nd }}$ Edn. Harper and Row, Hagerstown, MD, USA., Pages: 525.

Illman, R.J. and D.L. Topping (1988). Effects of dietary oat bran on fecal steroid excretion, plasma volatile fatty acids and lipid synthesis in the rat. Nutr. Res., 5:839-846.

Imik H., M. Aydemir Atasever, M. Koc, M. Atasever and K. Ozturan (2010). Effect of dietary supplementation of some antioxidants on growth performance, carcass composition and breast meat characteristics in quails reared under heat stress. Czech J. Anim. Sci., 55: 209-220.

Jaafar, S.F., A.A. Abdelkareem, H.M. Hassan, I. Elsadik, Amal Z. Sifaldin and H.M. Taha (2016). Gum Arabic improves semen quality and oxidative stress capacity in alloxan induced diabetes rats. Asian Pacific Journal of Reproduction, 5: 434-441.

Josephine, A., k. Nithya, G. Amudha, C.K. Veena, S.P. Preetha and p. Varalakshmi (2008). Role of sulphated polysaccharides from Sargassum wightii in cyclosporine A-induced oxidative liver injury in rats. BMC Pharmacol., 8:1-9.

Kaddam, L., F. Imad, A.E. Omer, A.A. Haydar (2015). Gum Arabic as novel anti-oxidant agent in sickle cell anemia, phase II trial. BMC Hematology, 17:4-10.

Kamal Ebtihal, Lamis AbdelGadir K ,Maha Dahawi, Montaser Osman, Mohammed Abdelraman Salih, Alnour Alagib and Amal Saeed (2018). Gum Arabic Fibers Decreased Inflammatory Markers and Disease Severity Score among Rheumatoid Arthritis Patients, Phase II Trial. International Journal of Rheumatology, 1-6.

Kaplan, L.A. (1984). Glucose. Clin Chem. The C. V. Mosby Co. st Louis. Toronto. Princeton; 10321036.

Kassem, A. (2015). Dietary Gum Arabic supplementation alter plasma and tissue antioxidant and free radical scavenging activities in Sprague Dawley Male Rats. Journal of Biology and Life Science, 6:129-138.

Kermauner, A. and A. Laurenčič (2008). Supplementation of rabbit diet with chestnut wood extract: effect on in vitro gas production from two sources of protein. In: Proceedings of the 9th World Rabbit Congress, Verona, June 10-13,pp. 689-693.

Khalil, S., A. Awad and Y. Elewa (2013). Antidotal impact of extra virgin olive oil against genotoxicity, cytotoxicity and immunotoxicity induced by hexavalent chromium in rat. IJVSM, 1:65-73.

Khojah Ebtihal, Y. (2017). Biological effects of low protein diet with Gum Arabic on rats chronic kidney disease. Advances in Environmental Biology, 11:60-69. 
Kishimoto, A., K. Ushida, G.O. Phillips, T. Ogasawara and Y. Sasaki (2006). Identification of intestinal bacteria responsible for fermentation of Gum Arabic in pig model. Curr. Microbiol, 53:173-177.

Lattimer, J.M. and M.D. Haub (2010). Effects of dietary fiber and its components on metabolic health. Nutrients, 2: 1266-1289.

Liu, H.W., X.F. Dong, J.M. Tong and Q. Zhang (2011). A comparative study of growth performance and antioxidant status of rabbits when fed with or without chestnut tannins under high ambient temperature. Animal Feed Sci Technol, 164:89-95.

Marai, I.F.M., A.A.M. Haeeb and A.G. Gad (2007). Biological functions in young pregnant rabbit does as affected by heat stress and lighting regime under subtropical conditions of Egypt. Trop Subtrop Agroecosyst, 7:165-176

McKee, J.S. and P.C. Harrison (2013). Supplemental ascorbic acid does not affect inferred heat loss in broiler chickens exposed to elevated temperature. J. Therm Biol., 38:159-162.

Mohamed Heba A., Nada Ahmed S., Neamat Hanafi, Hala F. Zaki and Sanaa A. Kenawy (2015). The reno-protective effect of Gum Arabic in gamma-irradiated and cisplatin treated rats. International Journal of Scientific and Research Publications, 5:1-11.

Nasir, O., A.T. Umbach, R. Rexhepaj, T.F. Ackermann, M. Bhandaru, A. Ebrahim, F. Artunc, D.S. Kempe, G. Puchchakayala, B. Siraskar, M. Foller, A. Saeed and F. Lang (2012). Effects of Gum Arabic (Acacia senegal) on renal function in diabetic mice. Kidney Blood Press. Res., 35: 365-372.

Nasir, O., F. Artunc, A. Saeed, M.A. Kambal H. Kalbacher, D. Sandulache, K. M. Boini, N. Jahovic and F. Lang (2008). Effects of Gum Arabic (Acacia senegal) on water and electrolyte balance in healthy mice. J. Ren. Nutr., 18: 230-238.

NRC (1977). Nutrient requirements of rabbits, 2nd Revised edn. National Academy of Sciences, Washington, DC.

Pal, R., Mangal Sain Hooda, S.B. Chain and S. Janardhan (2014). Hepatoprotective Activity of Acacia senegal Pod against Carbon Tetrachloride-Induced Hepatotoxicity in Rats. Int. J. Pharm. Sci. Rev. Res., 26: 165-168.

Park, E.Y., H. Murakami and Y. Matsumura (2005). Effects of the addition of amino acids and peptides on lipid oxidation in a powdery model system, J. Agric. Food Chem., 53:8334-8341.

Patel, S and A. Goyal (2015). Applications of natural polymer Gum Arabic: A Review. International Journal of Food Properties., 18:986-998.

Payne, R.L. and L.L. Southern (2005). Changes in glutathione peroxidase and tissue selenium concentrations of broiler after consuming a diet adequate in selenium. Poult Sci., 84:1268-1276.

Priscilla, D.H., and P.S.M. Prince (2009). Cardioprotective effect of gallic acid on cardiac troponin-T, cardiac marker enzymes, lipid peroxidation products and antioxidants in experimentally induced myocardial infarction in Wistar rats. Chem Biol Interact., 179:118-124.

Rehman, K. U., C. N. Codipilly and R. A. Wapnir (2004). Modulation of small intestinal nitric oxide synthase by Gum Arabic. Exp Biol Med., 229: 895-901.

Reitman, S. and S. Frankel (1957). A calorimetric method for the determination of serum Glutamic, Oxaloacetic and Pyruvic transaminases. American Journal of Clinical Pathology., 28:56.

Sadeek Eman F. A. (2018). Effect of Arabic Gum as Prebiotics and Lactobacillus casei Shirota (LcS) as Probiotic on Oxidative Stress and Renal Function in Adenine- Induced Chronic Renal Failure in Rats. European Journal of Nutrition and Food Safety., 8:29-46.

Tabacco, A. F. Meiathini, E. Moda and P. Tarli (1979). Simplified enzymic/colorimetric serum urea nitrogen determination. Clin Chem., 25:336-337.

Tageldin Samia, K.F. Elkhalifa and A. Khadija (2006). The effects of Gum Arabic on body weight and some blood elements in New Zealand cross California and Baladi rabbits. Pakistan Journal of Biological Sciences, 9: 96-98. 


\section{El-Ratel et al}

Tawfeek, S.S., K. Hassanin and I.M.I. Youssef (2014). The effect of dietary supplementation of some antioxidants on performance, oxidative stress, and blood parameters in broilers under natural summer conditions. J World's Poult Res., 4:10-19.

Thomas, L. (1992). Enzymatic colorimetric determination of cholesterol. Labor ND Diagnose. $4^{\text {th }}$ Ed. Uchiyama, M., M. Mihara (1978). Determination of malonaldehyde precursor in tissues by thiobarbituric acid test. Anal Biochem., 86:271-278.

Ushida, K., H. Hatanaka, R. Inoue, T. Tsukahara, and G. O. Phillips (2011). Effect of long term ingestion of Gum Arabic on the adipose tissues of female mice. Food Hydrocolloids, 25:1344-1349.

Valzitidis, H. (1977). Estimation of total serum proteins by Biuret method. Clinical Chemistry, 23:908.

Wyasu, G. and N.Z.J. Okereke (2012). Improving the film forming ability of Gum Arabic. J. Nat. Prod. Plant Resour., 2:314-317.

Xuan, N. T., E. Shumilina, O. Nasir, D. Bobbala, F. G“otz, and F. Lang (2010). Stimulation of mouse dendritic cells by Gum Arabic, Cellular Physiology and Biochemistry, 25: 641-648.

الاداء الانتاجى ، صفات الأبيحة ، مستوى الاهون ، حالة مضادات الاكسدة والمناعة للأرانب النامية المعاملة بالصمغ العربى تحت ظروف الصيف فى مصر

ابراهيم طلعت الرطل 1 ، رحاب فوزى صديق عبد الفتاح اسماعيل2ّ و سارة فكرى فودة 3 23 3 قسم انتاج الحيواج الدواجن- كلية الزراعة جامعة دمياط ـ مصر.

تهذف هذه الدر اسة الى تقييم تأثير الصمغ العربى كمضاد للأكسدة فى علائق الار انب النامية على خصائص النمو والذبيحة الذيحة، معاملات

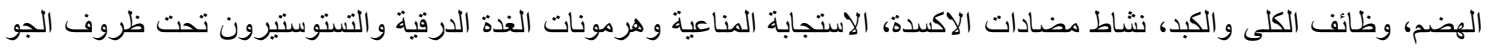

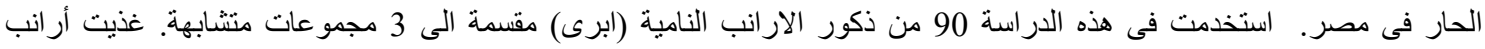

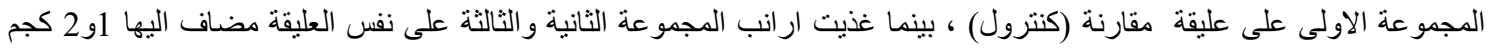

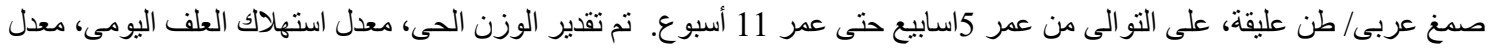

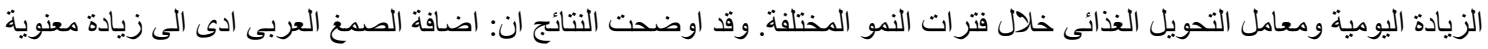

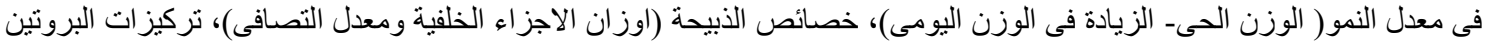

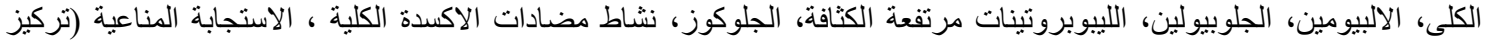

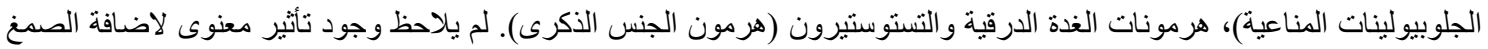

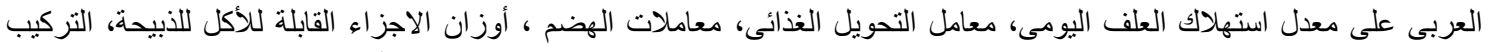

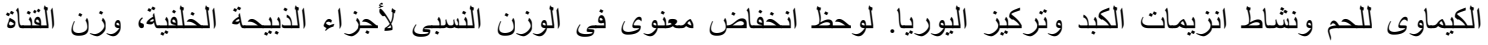

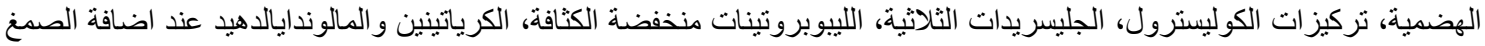

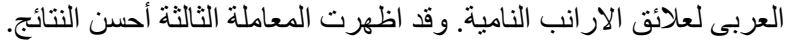

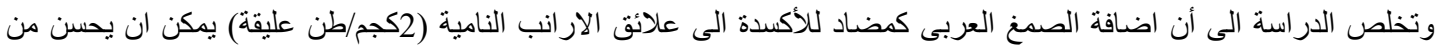

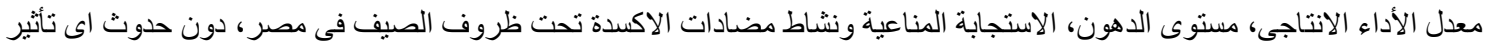

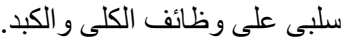

